\title{
CONTROLLING POLICE CONDUCT: ALTERNATIVES TO THE EXCLUSIONARY RULE
}

\author{
JERRY V. WILSON * AND GEOFFrey M. Alprin**
}

Expansion of the exclusionary rules through recent Supreme Court decisions is believed by many to be the most effective means of controlling police misconduct. The authors contest this view on two grounds. First, the police are not the sole, nor even necessarily the principal, offenders against whom the exclusionary rules should be aimed. Responsibility for the perpetuation of illegal police practices must instead be apportioned amongst all branches of the criminal justice system. ${ }^{1}$ Second, practical alternatives, or at least supplements, to the exclusionary rules do exist. Procedural rule-making by police departments themselves provides a solution which is both comprehensible to the policeman on the street and sufficient to satisfy the citizen's constitutional guarantees. In addition, police self-education can be served by police review of cases abandoned at the prosecutorial level to discover patterns of impermissible police conduct. Although this article necessarily centers on possible controls of police conduct, the authors feel compelled by their own allegiance to the police craft to disclaim, at the outset, any implication that they consider the police as the primary villains in a system where everyone else is carefully observing the rules.

\section{The Reality of the Process of Criminal Justice}

Before we confess certain indiscretions of the police, which we shall, let us first examine some of those compromises which are made by prosecutors and judges in order to accommodate stated rules to their own convenience. It should not be surprising that police officers, observing these compromises being continually ar-

\footnotetext{
* Chief of Police, Metropolitan Police Department, Washington, D. C.

** General Counsel, Metropolitan Police Department, Washington, D. C.

${ }^{1}$ An exchange between Congressman Charles E. Wiggins of California and A. Kenneth Pyc, Professor (then Dean) of Law at Duke University, is germane to this point, although contrary to the view of the authors. Congressman Wiggins asked Professor Pye whether he had "any recommendations for regulating police conduct short of exclusionary rules?" In response, Dean Pye suggested that the most suitable substitute for the exclusionary rules in terms of efficiency would be to vest general responsibility for all law enforcement, including the administration of the police department, in the prosecutor for cach judicial district. Hearings on the Improvement and Reform of Law Enforcement and Criminal Justice in the United States Before the House Select Comm. on Crime, grst Cong., rst Sess., at 686-87 (I969). Our purpose here is not particularly to quarrel with either Congressman Wiggins or Dean Pyc, for Congressman Wiggins' question and Dean Pye's response are not unique within the milieu of attitudes which view the exclusionary rules as being designed principally to control police conduct. Our purpose, indeed, is to use their exchange as a point of reference from which to discuss whether the fault for an inappropriate arrest, search, seizure, or improperly obtained confession ought to be viewed as resting solely with the police or, rather, in the past and even now, with other, presumably more sophisticated, elements of the criminal justice system.
} 
ranged, tend at the initial stage of the criminal justice process to employ these same or similar compromises for their own convenience.

For example, in the District of Columbia, as in most jurisdictions, petty larceny ${ }^{2}$ is a prevalent offense and consequently a frequent cause for arrest. It is a safe guess that, prior to I953, a very high proportion of petty larceny arrests were unauthorized by law, since they were misdemeanors not committed in the presence of the officer and therefore required arrest warrants. ${ }^{3}$ Certainly, the simple fact that a warrantless petty larceny arrest was illegal did not deter the prosecutor from prosecuting nor the court from convicting, unless the arrestee happened to be a citizen of some substance who could afford the services of a reasonably competent up-town attorney. And the rookie police officer, fresh from the Police Academy, quickly graduated to a school of higher learning which specialized in practicality and convenience. He learned soon enough that his Academy training on warrant requirements for misdemeanor offenses not committed in his presence was something less than a binding rule in the college of practical police, prosecutorial, and judicial procedures. This state of affairs continued until the Police Department itself pressed for special statutory authority to legitimatize arrests for petty larceny not committed in the presence of the officer where the property was still in the custody of the arrestee. ${ }^{4}$

Another example of a simply stated rule of law which has been compromised by judicial practicality into something other than what it says is the celebrated Mallory rule. Rule 5 (a) of the Federal Rules of Criminal Procedure requires that "an officer making an arrest ... shall take the arrested person without unnecessary delay before the . . o officer empowered to commit persons charged with offenses . . . ." The wording is clear and the requirement of the rule is mandatory. Does it mean what it says? Or, more appropriately, should we teach rookies the clearly stated command of the rule or should we teach them what we know the rule has come to mean since Mallory was decided in I957? It is not our intention to engage in the arguments propounded by some expert lawyers that, on the basis of the history of its language, Rule 5(a) was never intended to have the meaning given it by the Supreme Court. The police point of view we seek to represent here certainly is not based on such a sophisticated understanding of the history of the rule. Instead, the police view is based on a knowledge of what Rule 5 (a) does not mean as a practical matter in courts. For example, it did not in 1954 and does not in I972 mean that a judicial officer must be awakened in the middle of the night so that an arrested

${ }^{2}$ D. C. CODE $\$ 22-2202(1967)$.

${ }^{3}$ D. C. CoDE $\$ 4-140$ ( 1967 ), originally enacted in substance in 1862 and, subject to certain exceptions, still the law today. Together with D.C. CODE $\$ 4$-I4I (I967), it prescribes the traditional common-law arrest powers of police officers.

"Law of June 29, x953, ch. 159, $\$ 207,67$ Stat. 96. That section remained in effect until I97, when it was replaced by D. C. CoDE $\$ 23-581$ (a) (Supp. IV r97r) which allows probable cause arrests for persons believed to have committed or be committing petty larceny if the officer believes that "unless immediately arrested, [the offender] may not be apprehended, may cause injury to others, or may tamper with, dispose of, or destroy evidence."

${ }^{E}$ Fed. R. CruM. P. 5 (a); Mallory v. United States, 354 U.S. 449 (I957). 
person can be presented to him "without unnecessary delay" unless an unusually important case is involved. ${ }^{\circ}$ And it did not mean in I954, nor does it mean now, that a person arrested at 3:00 P.M. on a Saturday afternoon must be presented before the regular court session on Monday morning, again except in the exceptional case which might be expected to draw substantial public attention. Certainly, in 1954, the plain language of Rule 5 (a) did not mean that a prosecutor would not prosecute, nor that a court would not convict, nor that a United States Court of Appeals would not uphold the conviction of a rapist on the basis of a confession obtained during a seven and one-half hour delay from arrest to presentment. ${ }^{7}$

Police officers in 1954 could read Rule $5(\mathrm{a})$; indeed it had been printed in the Police Manual for many years. ${ }^{8}$ Additionally, in I954, they had available for their guidance and were taught in the Academy the Supreme Court's pronouncements in $M c N a b b^{9}$ and $U_{p s h a w .}{ }^{10}$ But the more important guidance which they quickly received was an appreciation, as a practical matter, of what Rule 5 (a) cases the prosecutor would prosecute and the courts would accept, irrespective of the stringent written requirements of the rule. Yet, when the Supreme Court decided Mallory, the rule of that case quickly came to be accepted as a vehicle to "control police misconduct," even though there was no conduct of the police in that case other than that which had been regularly reviewed and upheld for years by the prosecutor and the courts. No one suggested in the analyses and commentaries which followed Mallory" that the decision was also aimed at the "misconduct" of the prosecutor, magistrate, trial and appellate judges, all of whom, if there were misconduct disclosed by the facts in Mallory, equally should have shared the blame.

All of the foregoing is not an argument against the premise that, since the police are, after all, the initiators of almost all criminal prosecutions, the exclusionary rules are basically designed for the purpose of controlling the processes by which they initiate those cases. Rather, the foregoing is meant to illustrate the convenient ambivalence with which the Bench and Bar apply the exclusionary rules. In practice, the rule is applied so as not to seriously disrupt the system's tendency toward mass produced justice in unimportant cases involving poor people. Under this approach, judges and lawyers are conveniently spared the indignity of working nights and

\footnotetext{
"Not only does the "without unnecessary delay" clause of Rule 5 (a) apparently not apply to nighttime hours, holidays and most of a normal weekend, but during regular working days cases not fully "papered"- that is, cases in which the prosecutor has not completed his preparation of the documents necessary to present the arrestee to either the Superior Court or United States Magistrate-by 4.00 P.M. will not be accepted for presentment until the following morning. Thus, in effect, persons arrested in the early afternoon on a normal workday cannot be presented in the usual course of events for approximately eighteen hours.

${ }^{7}$ Mallory v. United States, 236 F.2d 70I (D.C. Cir. x956), rev'd, 354 U.S. 449 (1957).

${ }^{8}$ Manual of the Metropolitan Police Department of the District of Columbia, ch. VI, $\$ 4$, p. 50 (1948).

${ }^{9} \mathrm{McNabb}$ v. United States, 318 U.S. 332 (I943). For further clarification of the McNabb rule, sce Mitchell v. United States, 322 U.S. 65 (I944).

${ }^{10}$ Upshaw v. United States, 335 U.S. 4 Io (r948).

${ }^{11}$ See, e.g., Hogan \& Snee, The McNabb-Mallory Rule: Its Rise, Rationale and Rescue, 47 GEo. L.J. I (1958).
} 
weekends when most arrests are made. ${ }^{12}$ If our premise is true, it is not difficult to understand why the exclusionary rule system has essentially come to be recognized by some as a failure..$^{13}$ For it is only natural to expect police officers, who are generally taught clear, unambiguous rules in recruit academy, to become cynical of them when they observe, on a daily basis, those very same rules applied unevenly and sometimes arbitrarily by prosecutors and judges. As might be expected, the young police officer soon learns to take his cues from judges and prosecutors and learns to circumvent the written rules where he can in order to obtain reliable probative evidence.

In a system where the courts and the prosecutors themselves honor the exclusionary rules only to the extent dictated by their own practical convenience, the effects of the rules are bound to be subtle and spasmodic. Furthermore, on any specific issue the applicable rule itself is often unclear because (I) it is constantly changing as new cases are decided; (2) there is a natural hesitance on the part of the prosecutor to develop specific guidelines for the police until new rules have been shaken down through several decisions; and (3) more importantly, in most jurisdictions there is no effective means to develop adequate guidelines on new decisions or to disseminate such guidelines to the police of that jurisdiction. And even after the shake-down process is substantially complete, it is a simple fact of judicial life that any particular rule may be subject to as many differing shades of interpretation as there are judges available to interpret it. This problem is especially acute in a large city, such as Washington, D.C., where there are over fifty trial judges and over twenty appellate judges sitting on a daily basis. Thus, the net effect many times is a hazy rule, announced in a judicial opinion obviously not written for policemen, and enforced in the courts on a rather haphazard basis, sometimes with diametrically opposite results in cases presenting identical fact patterns. Such is not the stuff out of which the police are effectively policed.

Even if the boundaries of permissible conduct were clear and courts were consistent in their own applications, it would still be difficult to measure the extent of police compliance with proper procedures. Justly or not, in most of America the local Chief of Police or Sheriff is the public official held primarily responsible for

\footnotetext{
${ }^{12}$ Our point applies to far more than the Mallory rule. The courts, for example, have long favored searches made by law enforcement agents on the basis of properly obtained search warrants. In fact, close search and seizures questions may validly be decided in favor of the Government if a search warrant has been obtained. See United States v. Ventresca, 380 U.S. Io2 (1965). So it would be natural to expect that a reasonably accessible pool of judges would be available for warrant review and approval purposes at night, when the need to make house searches most frequently arises. Not so, at least in the District of Columbia, although a single emergency judge and magistrate are ostensibly on call during non-business hours under emergency procedures in effect in the District's Superior Court and U.S. Magistrate's Office. These procedures are used sparingly by officers who are naturally reluctant to disturb a judge at home during late evening hours, and who know that if they must awaken a judge for search warrant purposes, the case on which they are seeking a warrant had better be a very important matter.

${ }^{23}$ The various statements of discontent with the exclusionary rule system are collected in the appendix to Mr. Chief Justice Burger's dissent in Bivens v. Six Unknown Agents of Federal Bureau of Narcotics, 403 U.S. 388,424 (I97I).
} 
preventing and/or reducing the incidence of crime. Although, if he is articulate, he may be able to rouse some public opinion against other elements of the criminal justice system by pointing out their responsibilities in the process, in the final analysis it will be the Chief of Police who will receive the complaint letters and citizens' contingents demanding that something be done about crime.

Quite naturally, if the Chief is reasonably responsive to public sentiment, he will pass such pressures on to his subordinates. And at the bottom of the pyramid, the detective and the patrolman will feel a subjective pressure to reduce crime which they will translate into an objective pressure to close cases and arrest offenders. In most modern police departments, the injunction to close cases and arrest offenders includes an assumption that the closures will be valid ones and that the arrests will be procedurally correct. The problem which the police administrator faces, however, arises from the difficulty in assessing on a realistic basis the quality of the cases being made. He can give the detective a specified number of assignments and can hold him accountable for the number of cases remaining open and the number of cases closed within a specific period of time. He can, even without establishing specified arrest quotas, hold both the detective and the patrolman responsible for making an "acceptable" number of arrests. He cannot, however, with any fairness to his men, hold them accountable, on any reasonable statistical basis, for the number of cases successfully prosecuted in a system where success or failure of a prosecution rests on so many factors and so many compromises which are totally beyond the control of the arresting officer and so often have absolutely nothing to do with the quality of the arrest. ${ }^{14}$ Given this systemic problem in realistically assessing the quality of the individual police performance, there is room to question how much we will ever know about whether the exclusionary rules even affect police practices, except in the most important cases. ${ }^{15}$

\section{Alternatives to the Exclusionary Rules}

If, because of ambiguity in pronouncement, inconsistency in application, or difficulty in measuring effects, the exclusionary rule system is too subtle a device to control effectively police processes, we are bound to ask what improvements are possible. It

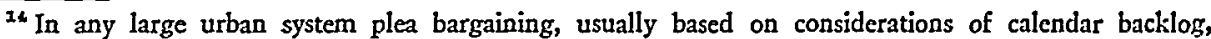
systematically affects the disposition of criminal cases. It is not unusual, for example, for an armed robber, validly arrested for two, three or more separate armed robberies, to plead guilty to one such offense in return for dismissals in the remaining cases. The point is not that plea bargaining is necessarily an evil phenomenon, although the authors believe it is far too prevalent for certain offenders and certain offenses, but rather that in such a system a realistic assessment of police performance based on final results in court is unfair, inaccurate, and generally impossible.

${ }^{15}$ As developed more fully below, it is important to keep in mind the fact that in any large court system the great majority of criminal cases is disposed of one way or another before reaching the court. Thus, the court observes police conduct in only a small percentage of actual criminal cascs. Even more significant in terms of judicial control of enforcement agencies is the fact that the courts seldom if ever have occasion to observe the many activities of police agencies which do not involve criminal cases.
} 
is surely unrealistic to suggest that the exclusionary system be discarded, notwithstanding its apparent faults, when no one has yet devised other suitable means to replace it. ${ }^{16}$

An alternative to exclusionary rules which is sometimes suggested is the police disciplinary process. But that process suffers from much the same dysfunctions of subtlety and intermittence as the exclusionary rules, and has some peculiar disabilities of its own. Police trial boards have been effective in many jurisdictions in eliminating gross abuse of prisoners, such as third degree methods of several generations ago. It would be unreasonable to argue, however, that the police officer who made an extra-legal arrest for petty larceny in the early I950's should be fired for doing so unless one argues with equal vigor that the prosecutor who prepared the case should be disbarred and that the judge who convicted the arrestee should be impeached. Aside from this impracticality, the use of the disciplinary process as a method of insuring appropriate handling of cases has perhaps an even greater disability in the fact that police discipline, like appellate court decisions establishing a particular exclusionary rule, operates on a case-by-case basis, far too unsophisticated to properly instruct police officers in precisely what is expected of them. The great problem with the case method, as is well-known, is that each decision informs all who become aware of it of precisely what is expected of them in a precisely similar case. The rules so established still leave a great deal of room for interpretation and argument in even slightly dissimilar cases, with the result that it may take many years of evolution to broadly implement a single rule. Consequently, if a police officer is convicted by a police trial board of unnecessarily beating a prisoner and breaking his nose, other officers observing the process have a choice of lessons to learn from the incident. They can learn either (a) that they should not unnecessarily beat a prisoner, or (b) that when they unnecessarily beat a prisoner, they should do so without breaking his nose.

It seems to us that the police disciplinary process is doomed to suffer the same failures as the exclusionary rules in attempting to control the manner in which police officers make cases unless it is complemented by the development of a process which tells the officer exactly what is an acceptable way of making a case and which means what it tells him. Such a process, the publication of clear guidelines to the statutory and case law, only recently has begun to be used in larger jurisdictions. It is likely to find increasing popularity in the years ahead as its effectiveness is fully exploited.

Police officers want to be told what to do. There has always been an unfortunate, and generally untrue, myth that policemen would actually prefer to short-cut the system. The myth has grown out of the fact that from time to time-under the

\footnotetext{
10 "Although I would hestitate to abandon it until some meaningful substitute is developed, the history of the Suppression Doctrine demonstrates that it is both conceptually sterile and practically ineffective in accomplishing its stated objective." Mr. Chief Justice Burger dissenting in Bivens v. Six Unknown Named Agents of Federal Bureau of Narcotics, 403 U.S. 338, 4r5 (I97r).
} 
pressures of public sentiment, of empathy for the victim he has seen, of frustration at observing a clearly (but not legally, or at least not legally before certain judges) identified offender escaping what he considers justice, of perception of widespread compromises throughout the process-an officer does indeed short-cut the system. But a far greater influence than the foregoing incentives leading him to short-cut the system is that the system itself is both ambiguous and ambivalent about short-cutting. Where clear-cut guidelines are laid down, and particularly when they are laid down and enforced by the police organization itself, policemen tend to comply with them and, whether they like them or not, learn to live with them.

What has deterred until now the development of adequate guidelines? Two factors have been at work. First, there has been an unwillingness on the part of prosecutors, whether because of lack of manpower, satisfaction with the status quo, or simple disinterest in the problem, to express clearly to police agencies simply applied interpretations of sophisticated court rulings. Second, police agencies have evidenced an unwillingness, either because of concern with taking on themselves responsibility for eroding police power or because of lack of legal expertise, to establish and enforce guidelines in connection with the making of criminal cases. What has occurred in the last few years, however, especially with the advent of police legal offices, has been a new readiness and ability of police agencies to develop and publish detailed rules for their personnel, which can be read, studied, and then applied by the officer in the field on a moment's notice.

Perhaps the earliest development of reasonably comprehensive guidelines in the law occurred, not in an area governed by exclusionary rules, but with regard to the use of deadly force. For years, police officials have known that it is generally unwise to shoot at a fleeing stolen automobile. Most automobiles are stolen by juveniles for joy-riding purposes and, although a felony is being committed, that felony is ordinarily not so serious as to justify taking a human life. ${ }^{17}$ This principle was recognized in other cases as well and it was generally known that the simple distinction between misdemeanor and felony was not a sufficient criterion for justifying the use of deadly force in an age when there are so many benign felonies. ${ }^{18}$ Still, even today, many police agencies simply instruct their officers in the common law authority for use of deadly force and caution them to use their individual discretion for certain felonies. Many others, however, have begun to develop precise guidelines so that, as nearly as possible, the department administrator, not the least intelligent officer on the force, is the one who decides what felonies will be cause for use of

\footnotetext{
${ }^{27}$ D.C. CODE $\$ 22-2204$ (I967). The maximum potential penalty for conviction of unauthorized use of a vehicle in the District is a \$rooo fine, imprisonment for five years, or both.

${ }^{18}$ In the District of Columbia, for example, the commission of the following non-inclusive list of felonies, standing alone, would have justified use of an officer's service weapon prior to enactment of the firearms regulations, cited infra at note I9: bigamy, D.C. CODE $\$ 22-601$ (1967); bribery, D.C. CODE \$22-70r ( 1967 ); embezzlement, D.C. CODE $\$ \S$ r20r, I202 ( 1967 ); false pretenses, D.C. CODE $\$ 22-x_{301}$ (I967); forgery, D.C. CODE $\$ 22-1401$ ( 1967 ); gambling, D.C. CODE $\$ 22-1501$ et seq. (1967); grand larceny, D. C. CODE $\$ 22-2201$ (I967); libel, D.C. CODE $\$ 22-230$ I (1967); perjury, D.C. CODE $\$ 22-2501$ (I967); and sodomy, D.C. CODE $\$ 22-3502$ (1967).
} 
deadly force. There may be some grumbling in the ranks and among some segments of the public when such guidelines are first published. But in the long run, the line officer is better served by having a rule under which he can defend his action than by having to base his defense on his individual judgment in each particular case.

In the District of Columbia, for example, guidelines have been created which attempt to distinguish realistically those types of felonies which reasonably justify the use of a police officer's service weapon. An officer who is attempting to arrest or prevent the escape of a felon is justified in using his weapon only if the felony "for which the arrest is sought involved an actual or threatened attack which the officer has reasonable cause to believe could result in death or serious bodily injury."10 'The effect of the regulation is substantially to remove felonies against a property interest alone, such as burglary in the second degree, ${ }^{20}$ from those which historically have justified a police officer's use of his service weapon.

Naturally, the existence of a finite regulation is no guarantee either that its strictures will be observed or that the public will believe that its strictures are being observed. In recognition of that fact, we in the District have created a board of senior police officials whose responsibility it is to review every incident in which a police officer's weapon is fired to insure that interpretation of the regulations throughout the department is uniform. Non-compliance with either the letter or spirit of the guidelines can cause any of a number of adverse disciplinary recommendations against the offending officer, including a trial board proceeding which may result in dismissal from the force. What is more significant in terms of creating an accepted substitute for outside control of individual police activities is the fact that the Board annually publishes complete statistics of its cases. These include the disciplinary recommendations made by the officer's commanding officer, its own recommendations, and the final decision of the Chief of Police. ${ }^{21}$ The statistics are made available to and receive significant attention in the local press, ${ }^{22}$ which in itself may constitute the ultimate means of controlling potential police impropriety.

More closely related to enforcement areas traditionally within the ambit of exclusionary rules is the District of Columbia Police Department's recent order dealing with pre-trial identification problems. ${ }^{23}$ Whatever the merits of the trilogy of land-

\footnotetext{
${ }^{10}$ Manual of the Metropolitan Police Department of the District of Columbia, ch. II, $\$ 2.4:$ (b) (2) (1972). Although the guidelines are City Council, not police, regulations, the point is the same.

${ }^{20}$ D.C. CODE $\$ 22-180$ I (b) (Supp. IV, I97I).

${ }^{21}$ In 1970, there were 154 incidents involving the firing of police service weapons. Out of this figure, commanding officers recommended disciplinary action in 25 cases. However, the Board recommended disciplinary action in 43 cases; and the Chief of Police confirmed disciplinary action in a like number of cases.

In $197 x$, there were $I 63$ such incidents. Commanding officers recommended discipline 46 times and the Board 47 times. Disciplinary action was confirmed by the Chief of Police in 45 cases.

22 See, e.g., "Policemen Disciplined for Gunfire," The Washington Post, April 12, 1972, § B at I; "Wilson Disciplined 45 for Arms Use," The Washington Evening Star, April II, I972, § B at I.

${ }^{23}$ District of Columbia Metropolitan Police Department General Order 304.7 (December, 1971). The identification order was originally published as Memorandum Order No. 16, Series 1970 (May, 1970).
} 
mark Supreme Court cases decided in I967 on the subject, ${ }^{24}$ the fact is that, as is so often the case with significant new judicial pronouncements affecting police operations, the decisions raised more questions for police administrators than they answered. The Supreme Court's reluctance to resolve questions not squarely presented, and thus to guide those affected by its opinions, flows from a direct constitutional command, ${ }^{25}$ but policemen are not very well policed by deferring critical issues for years until the precise question is properly presented and the Court decides to resolve it.

The Supreme Court's identification cases struck down as unduly suggestive a number of previously accepted police practices dealing with uncounseled confrontations between victim and alleged perpetrator, arranged for the purpose of determining whether an identification could be made. But not all such suggestive confrontations were invalidated. The decisions clearly left some leeway, in terms of time and circumstances, during which an uncounseled one-on-one confrontation would be upheld. How long that time period was, or how necessitous those circumstances must be, were issues left to be resolved in the future under the traditional common law case method. In the interim, police departments, far from being policed, were left to attempt to fathom for themselves the limits to which the confrontation exception might extend.

In March, 1970, the Department issued an order attempting to fashion simple rules of conduct for its line officers faced with identification problems. It chose, somewhat arbitrarily, a flat one-hour rule during which one-on-one street confrontations between victim and suspect were required. It was that simple. If a suspect were arrested within one hour of the time of the commission of the offense, in an area reasonably proximate to the scene of the offense, he had to be returned to the scene for purposes of identification; if arrested after one hour, he could not be so returned.

It is not the purpose of the authors to argue at length in favor of the wisdom of the one-hour confrontation rule. In balancing the interest in reliable, fresh identifications against the disadvantages of one-on-one confrontations which are of necessity at least somewhat suggestive, a thirty or ninety minute rule, or others, could with equal wisdom have been chosen. Nor is it our purpose to call attention to the fact that on a number of occasions since its promulgation local appellate courts have commended the identification order, including its other provisions dealing with line-ups and photographic identification procedures, and, in essence, accepted the Department's one-hour rule. ${ }^{28}$ Rather, the point is that, faced with a judicial pro-

\footnotetext{
${ }^{24}$ United States v. Wade, 388 U.S. 218 (1967); Gilbert v. Calif., 388 U.S. 263 (I967); Stovall v. Denno, 388 U.S. 293 (I967).

${ }^{25}$ U.S. Const. art. III, $\$ 2$ 2. See also Rice v. Sioux City Mem'l Park Cemetery, 349 U.S. 70 (I955).

${ }^{26}$ United States v. Perry, 449 F.2d I026 (D.C. Cir. 197I). The court there stated:

In the case at bar, we find ample justification for the questioned confrontation in the combination of the necessity appearing, the relatively short time interval [approximately one and onc-half hours], and the potentially reliable identification. We also note that, after this case arose, the
} 
nouncement instructing it in what could not validly be done, the Department on its own initiative undertook the responsibility, in an area fraught with constitutional overtones and exclusionary rule potentialities, of instructing its personnel with a mandatory, simply-applied rule which, perhaps because the rule is reasonable in itself or because the entire order reflects a responsible effort to fill the many gaps left by the decisions, the courts have apparently accepted. The result is a rule more readily understood by those who must use it and therefore more vigorously enforced by those who must enforce it.

The Department has attempted to repeat its apparent success in the identification area with an order dealing with automobile searches and inventories. ${ }^{27}$ Recognizing that a Rhodes scholar might have difficulty in applying the decisional law with respect to automobile searches, the order again attempts to provide reasonable, easilyapplied rules of conduct for line officers. One innovative characteristic of the order is the creation of various classifications of vehicles coming into the possession of the Department, and limiting inyentories of the contents of a vehicle solely to those classifications which might reasonably be held to justify them. ${ }^{28}$ Underlying the inventory sections was the hope that claims that the Department's inventory processes were merely exploratory searches in disguise would thus be avoided. Additionally, like the one-hour rule of the identification order, it was hoped that through a reasonable and responsible demonstration of police willingness to maintain internal controls, in an area which had for some time troubled the judiciary, ${ }^{29}$ the courts would be encouraged to accept an inventory rule which the police had created and with which they could live.

Even assuming that both the identification and automobile search orders finally

Metropolitan Police Department put into operation a regulation restricting on- and near-the-scene identification confrontations to suspects arrested within 60 minutes after the alleged offense and in close proximity to the scene. We see in this regulation a careful and commendable administrative effort to balance the freshness of such a confrontation against its inherent suggestiveness, and to balance both factors against the need to pick up the trail while fresh if the suspect is not the offender. We see no need for interposing at this time any more rigid time standard by judicial declaration.

449 F.2d at 1037 (emphasis added). See also United States v. Evans, 438 F.2d x62 (D.C. Cir. I97I). The identification order has also been cited "with approval" for other procedures not related to the sixtyminute confrontation rule. United States v. Ash, No. 22,340 (D.C. Cir., March I, I972).

${ }^{37}$ District of Columbia Metropolitan Police Department General Order No. 602.I (May, I972). The order was originally published as General Order No. 23, Series I97I (June, r97x).

${ }^{28}$ The order attempts to balance the need of the Department to safeguard property coming into its possession against the need to avoid the appearance of conducting full searches of automobiles, without probable cause, under the guise of an inventory procedure. It creates five classifications of vehicles coming into the Department's possession, and limits inventories only to those classifications which justify them. For example, if a person is arrested in a vehicle and there is no legitimate connection between the offense and the vehicle, the automobile is classified as prisoner's property, and must be disposed of, without inventory, in any lawful manner which the prisoner directs. On the other hand, if that vehicle had been used by the arrestee in the commission of a holdup and he is arrested for the holdup, the vehicle is to be classified as "evidence" and may be fully inventoried. District of Columbia Metropolitan Police Department General Order 602.I, Pt. I, $\$ \S B_{2}-B_{3}$.

${ }_{20}$ See Mayfield v. United States, 276 A.2d r23 (D.C. Ct. App. I97r); Pigford v. United States, 273 A.2d 837 (D.C. Ct. App. I97I); United States v. Pannell, 256 A.2d 925 (D.C. Ct. App. Ig69); Williams v. United States, I7o A.2d 233 (D.C. Mun. Ct. App. 196r). 
come to be accepted as reasonable rules of conduct, they certainly will not serve as even partial replacements for the exclusionary rules in those areas unless the Department develops methods for surfacing those cases in which police action fell short of that required by the order and enforcing the requirements of the order in those cases. As any police administrator knows, isolating cases in which ostensibly improper searches and seizures have occurred is a far more difficult proposition than determining when service weapons have been fired and uniformly requiring reports and investigations in those matters. Traditionally, except in the most acute and obvious circumstances of officer misconduct, criminal cases which the prosecutor decides not to prosecute because of an error in preparation likely to fall within one of the exclusionary rules have never been systematically brought to the attention of responsible police officials. Typically, the prosecutor informs the officer presenting the case that the case cannot be made because the incriminating evidence was obtained "improperly." The officer, who throughout his career has observed numerous properly prepared cases dismissed or compromised, simply chalks the matter up to the vagaries and mysteries which surround the decision-making process in a large urban courthouse. If his error actually caused the failure of the prosecution, he generally does not believe it and no higher police official to whom the officer is accountable normally learns why the decision was made or even that the case was dropped. There are exceptions, of course, usually in important cases which are or may become matters of public attention. But generally such critical decisions are made routinely and are invisible not only to the courts but even to higher officials in the police department and the prosecutor's office. The effect of the exclusionary rule in such cases, except to the extent that it ostensibly results in the freedom of an arrested (and quite possibly guilty) suspect, is miniscule.

In the District, we have recently begun an experiment in surfacing, for the benefit of higher officials in the Department, those non-prosecuted cases which before have never reached the attention of the courts and seldom have been reviewed within the Department. In cooperation with the local United States Attorney's Office, the Department has created a specialized unit, staffed with police officials, with responsibility for reviewing every case which is dropped by the prosecutor, for whatever reason. Errors in police procedures, whether of exclusionary rule character or not, are brought to the attention of the offending officer and his commanding official, who is required to insure that the officer is counseled and instructed in proper processes. The Case Review Section maintains records by officer and unit so that recurrent patterns of misconduct or procedural error can be observed and corrected. In those areas where direct Department orders apply, as, for example, the identification or automobile search orders, egregious or repetitive errors may be dealt with through the Department's disciplinary processes. To offset particularly significant patterns adversely affecting prosecution of cases, members of the section regularly 
instruct recruit and in-service training classes at the Department's Academy. Statistics are maintained by the Section and are made available to the public. ${ }^{30}$

If the experiment is successful, it may very well prove to be a far more effective control on police "misconduct" than any of the exclusionary rules have been for the simple reason that it will uncover an entire class of cases which the courts have never been privileged to review. If it is assumed that the prosecutor serves a screening function in his decisions about which cases to send to trial, then it is certainly conceivable that the courts have seldom reviewed the more serious cases of improper police procedures. A Fourth Amendment search or a Fifth and Sixth Amendment confession is either clearly proper, borderline, or clearly improper. Presumably, if a prosecutor is doing his job properly, he will allow the courts to see all of the first category, most of the second, and none of the third. Since it may be assumed that the most serious abuses occur in cases falling in the third category, it is here that the Case Review Section holds the highest promise, in terms of instruction, supervision and direction, of correcting those abuses at which the exclusionary rules were aimed in the first place.

\section{Conclusion}

The authors doubt that the exclusionary rules will ever be totally discarded, if only because of a natural reluctance on the part of the judiciary to relinquish to the prosecutor absolute control over determining the validity of executive branch conduct in criminal cases. ${ }^{31}$ But if police departments genuinely attempt to regulate themselves with responsible, reasonable, clearly-stated and easily understood rules of conduct in areas in which the exclusionary rules are presently operative, and to enforce those regulations fairly and openly, it seems conceivable that the courts will feel less of a necessity to invoke a process which, at its best, admittedly corrupts the truth-seeking function of a criminal trial. The result may very well be that the exclusionary system will be reserved only for unusual cases which slip through internal police controls or the true borderline situation which genuinely requires judicial attention. In the view of the authors, responsible rulemaking by police agencies, together with a systematic review procedure directed towards locating and correcting improper conduct, may accomplish the objectives which the exclusionary rules have historically sought but have never attained.

80 " $I$ in 5 Charges Dropped," The Washington Post, March 29, I972, § C at $I$, col. 8. The first statistical study of the unit covered the period from February $I_{3}$ to March 14, I972, and revealed that, out of 1433 cases presented by the police to the prosecutor in the Superior Court, 275, or I9.2\%, were dropped by the prosecutor immediately. Later statistical studies have indicated that the true "no-paper" rate may be somewhat higher. One measure of the success of the new unit will be the extent to which the average rate over a period of several months can be lowered in the future.

${ }^{31}$ Even while advocating an increased rule-making function for police agencies, one noted federal jurist recently commented that "the last word as to the propriety of police-made rules always remains with the judicial branch." McGowan, Rule-Making and The Police, $70 \mathrm{MrCr}$. L. Rev. 659, 675 (I972). Our quarrel is not so much with Judge McGowan's obviously valid premise as it is with the extent to which the judiciary has felt compelled in the last decade to utter its "last word." 